\title{
Border Disputes and Its Impact on Bilateral Relation: A Case of Nepal- India International Border Management
}

\author{
Toya Nath Baral \\ Former Director General, \\ Survey Department, Government of Nepal \\ Email: baraltoyanath@gmail.com
}

\begin{abstract}
This paper examines the historical events of Nepal-India international boundary. How the delineation and demarcation of international boundary was carried out, is strategically explained. Border water issues are raised. Encroachments and disputes due to river boundary are also discussed. Disputes on both Physical and artificial boundary and their impacts on bilateral relation is analyzed. Both positive and negative impact of an open border system between Nepal and India is discussed. Border problems are identified clearly. Initiatives taken how to resolve the border management issues are categorically presented. Strip mapping of boundary area was carried out using GPS and GIS technology and the maps of whole Nepal-India boundary, except Kalapani and Susta, are prepared jointly and signed by the joint technical committee assigned by the respective government.
\end{abstract}

Key Words: Boundary, encroachment, strip map, bilateral, dispute, demarcation

\section{Introduction}

Boundaries are manifestations of national identity. Delimitation of a boundary in a treaty is a crucial first step in boundary-making, but on its own delimitation is of limited value. For borderland populations, boundaries rarely have much meaning until they are identifiable on the ground - and it is arguable that it is only when a boundary has been physically demarcated that it can begin to function effectively. Many of the world's international boundaries have never been made visible on the ground, and many of those that have been demarcated have subsequently become invisible due to inefficient maintenance regimes.

Most countries' archives contain a wealth of material relating to international boundaries, much of which can be crucial to the understanding of boundary and territorial disputes. However, the size and complexity of many archives means that finding relevant material and compiling an accurate picture of the key issues is rarely a straightforward task.

\section{Evolution of International Boundary of Nepal with India and China}

Nepal has been regarded as an independent and sovereign country, from the ancient time to date. For thousands of years, the boundary of Nepal is surrounded by India to the three sides- south, east, and west and by China to the north. It is recorded that, at some period of history, the boundary of Nepal was extended to Tista River in the east and to Kangada fort in the west. Similarly, Nepal was extended to the confluence of the Ganga/Jamuan Rivers in the south and to the Himalayan range of Singatse and Tasilhunpo monastery in the north. In the course of time, the international boundary of Nepal happened to be limited to Satalej in the west, to the middle part of the Ganga River in the south and to the present Bangaladesh in the east. Then, there held war between Nepal and the East India Company- the then ruler of British-India. After then, being compelled, they signed on Sugauli treaty in 1873BS (4 March 1816 AD). Due to the Sugauli treaty, Nepal lost the land from the Mechi to Tista in the east and from the Mahakali to Satalej in the west and from Chure range to plain Tarai 


\section{9 | Journal of APF Command and Staff College}

in the south. Probably, being dissatisfied with the treaty, it was not signed by the then king and Prime minister from Nepal; a representative of Nepal signed it. In 1872, BS Paush 7 (December 11, 1816) the East India Company returned some snatched land from the Sugauli treaty of eastern Terai to Nepal. Similarly, when Junga Bahadur Rana helped to British people in solders revolution, then, in turn the British-India ruler, being happy, returned the western Terai (known as Naya Muluk- the districts are Banke, Bardiya, Kailali and Kanchapur) to Nepal in 1917 BS, Kartik 3 (November 1, $1860 \mathrm{AD})$ as a supplementary boundary treaty. After this treaty, the present border has been retained.This article mainly discusses two aspects of border management that Nepal and India have broad issues: Boundary Demarcation and Border Management.

\section{The Delineation and Demarcation of Nepal-India Boundary}

The Treaty of Sugauli of 4 March 1816, Supplementary Treaty of 11 December 1816 and Boundary Treaty of 1 November 1860 delineate the boundary of Nepal with India. The treaty of Sugauli was not signed by the King or Prime Minister/Maharaja but by only the courtiers Gajaraj Mishra and Chandra Shekhar Upadhaya. Nepal-India boundary has a comparatively recent origin and its present boundary delimitation and demarcation took place after the Anglo-Nepal War of 1814-16.

After the restoration of low land, southern borderline of Nepal with India runs through fertile plains, jungles, rivers and settlements as well. On the east there is the Mechi River and the watershed of Singhalila Range with hills and hillocks stand as the border. On the west, the Mahakali River runs all the way as the border line between Nepal and India.

The border demarcation work between Nepal and India was started with the spirit of the Treaty of Sugauli (ratified on 4 March 1816). Surveying and demarcation of border with the erection of pillars had been started just after monsoon season of 1816. The boundary line between two countries was surveyed and demarcated from 1816 to 1860/1882/1885/1906/1930-31/1940-41 dividing it into nine different sectors with the erection of masonry boundary pillars.

\section{Boundary Dispute and Encroachment}

The straight line between the two BP was drawn for the demarcation of the border in the forest areas, while demarcation in the cultivation land was made on the basis of village boundaries on the principles of mutual give and take and fluid boundary was honoured in river and rivulet segments immediately after the treaty of Sugauli 1816 A.D.

Absence of land marks on the topographical maps on the Indian side across the Nepal-India border has been the major reason behind the encroachments of Nepalese territory across the border. Since the Nepal-India boundary after the Sugauli treaty, there had been tremendous changes in the landscapes on either side of the border as compared to the natural landscapes. So there have been attempts to update the boundary treaty maps since 1981 by constituting joint technical level boundary committee by both Nepalese and Indian governments.

Before the independence of India, there existed a system of regular survey and supervision of NepalIndia boundary jointly conducted by officials of both the countries every year to oversee and find out encroachment, if any, on the boundary, ill-defined boundary, missing and damaged BPs, as well as misplaced BPs with objective to fix and place them in original position. After the independence of India and Nepal, no joint boundary survey has been conducted until the formation of Joint technical level boundary commission in 1981. Delay in the formation of JTBC resulted in several boundary disputes which remain unresolved up to 1981 . 


\section{Nepal India Joint Technical Level Boundary Committee}

Government of Nepal realized that condition of its southern territory and portion of eastern and western segment, are in miserable condition that may create problem in future. Considering all these facts, Nepal moved and talked diplomatically with India to formulate Nepal-India Joint Border Inspection Mechanism to keep the boundary clear and intact. Exchanging the diplomatic note, took almost a decade. After a long consultation/conversation and series of joint meetings, it was finally agreed on 25 February 1981 to work jointly to clear and maintain the boundary line between two countries intact. As a result, Nepal-India Joint Technical Level Boundary Committee (JTBC) was constituted in November1981 and it worked for 26 years before it was dissolved in January 2008. The JTBC was mandated for the maintenance of the boundary pillars along the Nepal-India boundary line as follows:

- Re-establish and reconstruct the boundary pillars that are found lost.

- Recording of encroachment along the boundary- Dasgaja and ask to manage and keep the boundary clean.

- Prepare the modality for periodic inspection to keep the boundary intact.

The JTBC used boundary maps prepared in different period in accordance with Sugauli Treaty that were accepted by both side. Nepal-India boundary is found $1880 \mathrm{~km}$ long of which $1240 \mathrm{~km}$ is land boundary and $640 \mathrm{~km}$ is river and rivulet boundary (fluid boundary). We have counted 60 boundaryriver and rivulets along Nepal-India boundary. About $200 \mathrm{~km}$. long is Mahakali River that is our western boundary and about $80 \mathrm{~km}$ Mechiriver that is our eastern boundary. 20km long Nepal-India boundary is along Gandakriver (Narsahi-Susta). The other 57 river and rivulets, counts to $340 \mathrm{~km}$. along Nepal-India boundary.

Government of Nepal and India decided to implement fixed boundary principle on 2045 B.S and JTBC started working accordingly on riverine segments, preparing strip maps and delineating boundary line on that strip map as per boundary base maps accepted by both side. Again in 1992 A.D, JTBC was mandated more additional works as follows:

- Prepare boundary strip map of 1:15000 scale covering 500 metres either side from boundary line and mark boundary line on that strip map.

- Show physical boundary line on the ground on the basis of boundary base map and transfer it on strip map thus prepared.

- Additional boundary pillars will be constructed so that they are inter-visible from one to another and straight line between the pillars.

- Additional boundary pillars will be constructed in riverine segments according to the fixed boundary principle.

- All boundary pillars will be numbered in sequence and same coordinate system will be established.

JTBC resolved all minor disputes during the field work and prepared strip maps of Nepal-India boundary and transferred the boundary line on the basis of boundary base map prepared after Sugauli Treaty. Major disputes of NarsahiSusta and Kalapani segment remain unresolved even after many intensive attempts made by JTBC. Various minor issues have been resolved and erected subsidiary/additional pillars and prepared strip-maps of the resolved areas. But the joint committee could not settle major issues of disputed portions of Susta and Kalapani. In fact, the Joint Technical Committee (JTBC) worked for 26 years and completed 98 percent of the boundary work. This unresolved portion of border consists of Kalapani-Limpiyadhura encroachment 17 km and Narsahi- 


\section{1 | Journal of APF Command and Staff College}

Susta $20 \mathrm{~km}$ ( $2 \%$ of the total length). There are cross-occupations, which need to be identified and look for amicable solution from both countries.

\section{Narsahi-Susta Dispute}

In NarsahiSusta, the Narayaniriver forms the India-Nepal boundary. But several large floods have reshaped the river, causing Indian encroachment into Nepal. Question of quantifying the disputed area precisely, is not possible until both side agree on a single boundary line. How ever there exists Indian encroachment. There were flood hazards during the monsoon period of 1845, 1954, 1972, 1980 and 1989, and the River Narayani changed its course in each and every heavy flood, leaving the Nepalese land on the east of the river.

So far as the Susta disputed area is concerned, it must be followed the original course of the River Narayani flown during the time of Sugauli Treaty, 1816-17. The original river course must be delineated and demarcated accordingly. This is the dispute of $20 \mathrm{~km}$ of the river course, as there are no Boundary Pillars on either side of the river.

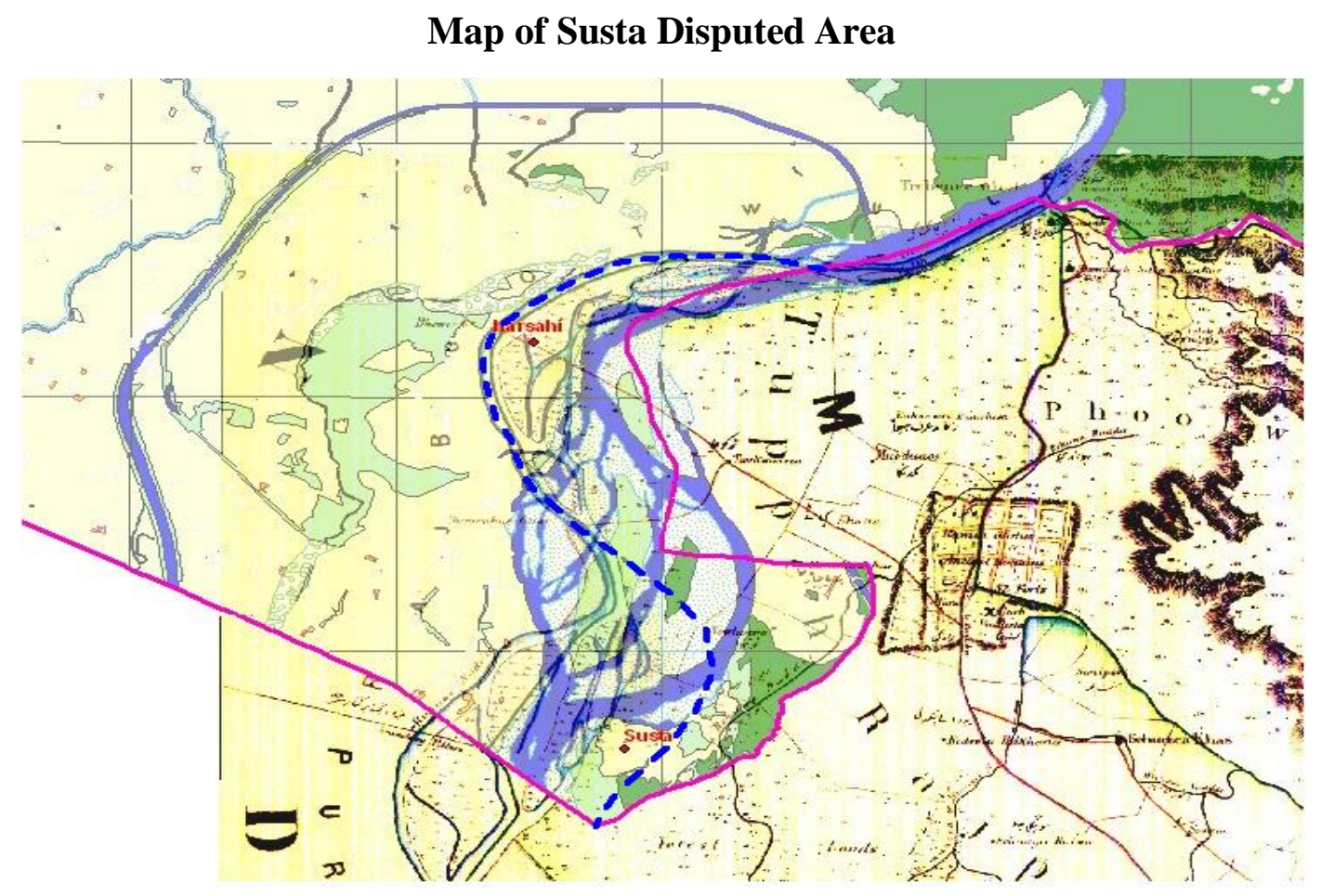

Narasahi-Susta: Blue dotted line is Indian claim, Green solid line is Nepalese claim

It is to be understood that Nepal and India have jointly adopted the 'Fixed Boundary Principle' on the river courses. Now the joint mechanism (Foreign Secretary Level) is working on these issues of Susta and Kalapani and let us hopes the said joint mechanism will produce amicable solution that will resolve these issues. India and Nepal, both government agreed to implement fixed boundary principle on river boundary area already in 2045 B.S. that will guide the way to resolve the issue (delineating the original river course of the time of Sugauli Treaty).

\section{Kalapani Dispute}

The Kalapani disputed area is located in the Greater Himalayas along the border of India, China and Nepal. It is located near the headwaters of the main Kali river. Nepal claims that the river to the west of Kalapani is the main Kali, hence the area belongs to Nepal. But India claims that a small River named Pankhagad, to the south of Kalapani, and the ridgeline on the east side of the Kalapani area is 
Baral: Border Disputes and Its Impact...| 32

the true border, hence the Kalapani area belongs to India. This dispute has remained unresolved from at least 1962 until the present. JTBC worked hard but, could not ascertain the spot of headwaters of main kali river, due to various versions of the boundary maps and documents of different period. The Sugauli Treaty signed by Nepal and British India on 4 March 1816 locates the Kali River as Nepal's western boundary with India. Subsequent maps drawn by British surveyors show the source of the boundary river at different places. This discrepancy in locating the source of the river led to boundary disputes between India and Nepal, with each country producing maps supporting their own claims.

\section{The Joint Signature on Boundary Strip Map}

Nepal-India Joint Technical Level Boundary Committee worked from 1981 to 2007 A.D. JTBC relocated the missing boundary pillars, reconstruction of the damaged and dilapidated boundary pillars, establishing additional boundary pillars where ever necessary to make it inter-visible, clear ten-yard+ ten-yard width no-man's land and preparation of strip-maps of both the sides of boundary line covering 500 meter either side. But it has not resolved the issues, such as KalapaniLimpiyadhura, identification of the source of river Kali and Narsahi-Susta dispute. These are the major issues and problems of demarcations of border between two nations. JTBC worked on the basis of institutional responsibility from the initial stage 1981 to the final stage (signing of the 182 strip maps of the Nepal-India boundary). Preparation of strip maps and delineating boundary line on those strip maps as per boundary base maps (boundary maps) prepared after Sugauli treaty and agreed by both side, were used during the phase of boundary map updating. We need to understand this is not a new boundary demarcation and just an updating process. No strip maps were prepared on Narsahi-Susta and Kalapani-Limpiyadhara segments as JTBC couldn't reach any agreement on those two segments of Nepal-India boundary. There exist cross-border occupations because of shifting of river boundary and subsequently implementation of fixed boundary principle, which need to be identified and look for amicable solution from both countries.

\section{Border Management}

Border management is a mechanism to ensure the security of national borders and to regulate legitimate movements of goods and people on borders to meet various needs of the nation by cultural-social-economical interactions which are performed through the borders. Nepal-India border management consists of domestic and joint institutional mechanism, border area development programmes, implementation of integrated check post in customs, joint border working group, joint mechanism of reconcilement of border disputes and mobilisation of security forces and etc. Proper border management ensure the security of border areas, welfare of the border population and integrating them in the national mainstream, prompt resolution of border related problems and maintaining cordial relations with neighbouring countries and this will require a certain amount of diplomatic acumen on the part of border guarding force commanders and a clear-cut mutually acceptable framework for solving issues.

\section{Impact of Border Disputes on Bilateral Relations}

Like most boundary dispute, those of India with its neighbours are symptomatic of wider bilateral relations. Boundaries are manifestations of national identity. They can be trip-wires of war. Recent developments in South Asia suggest that peaceful resolution of these disputes is receding from reach. 


\section{3 | Journal of APF Command and Staff College}

An open border system between Nepal and India has been in the best interest of the border inhabitants of the two countries, which is a model for other countries of the world. But there is no such reciprocity among the border inhabitants along the two sides of the Nepal-China border. In view of the fact that both India and China happen to be the fastest growing economies of the world, Nepal should take maximum benefit from them. Towards this end, Nepal should attract its two neighbours to maximize its efforts in Nepal's development activities. There is nothing wrong with the Indian or Chinese aided projects in so far as they support the Nepalese economy. But what is intriguing is that one of the neighbours is aggressive in increasing its area of influence in Nepal, while the other does not want to lose its traditional foothold in the country in view of its social, cultural and economic ties. It is feared if it could intensify the rivalry between the two countries, which might ultimately undermine Nepal's fragile democracy if not handled properly.

In the democratic peace literature, conflict and trade are mutually exclusive. Conflict disrupts trade, and, therefore, states would like to avoid any loss of trade benefits. Therefore, they pursue a peaceful path to solve their disagreements rather than resorting to a military solution (Doyle 1999). States that trade with one another are less likely to be involved in a conflict. This established strong evidence that trade is lower between territorial claims. This leaves us unable to determine whether former territorial claimants were able to increase their trade after settling the claim.Bilateral trade between states should increase substantially after they settle their territorial issues through peaceful means, although there should be little impact after a territorial claim is resolved violently.Even if there exists border disputes between Nepal and India, both government are aware of not to hijack their interests on political and trade business.

India's strategic interests in Nepal follows from its desire to maintain a peaceful international environment create friendly relations with all the states and especially with neighbours, prevent any attempt towards the formation of anti-India blocs and finally develop new markets, investment opportunities and resources to stimulate its economic growth. To achieve all these objectives, it is necessary for India to have friendly relations with Nepal, despite the inherited bilateral issues. On the other hand, India's own focus on the internal development encourages it to cultivate positive relations with Nepal. However, the attitude within India towards forging cordial relations with Nepal remains mixed to some extent due to the historical legacy of Nepal-India relations.

Nepal and India with similar culture, society, share a number of interests especially in the areas of domestic developments, economic reform. India is experiencing a rapid economic growth while Nepal is facing extreme trade deficit with India. Some of the major bilateral issues are: cross-border terrorism, illegal imports of arms and ammunitions, cross-border crime, infiltration of refugees, peace and security, construction of dams and embankment submerging the international border line.

There are factors within and outside between Nepal and India which still impacts their relations, for instance, border disputes and political issues are more prominent and recently, the water issue has also surfaced in the bilateral relations between Nepal and India. These bilateral issues will not only effect on their present relations but have a negative impact on their future relations as well.

\section{Water Issues between Nepal and India}

In all the times, water is regarded as a precious commodity and is essential for human existence. That is why, its possession bestows power. The preciousness and possession in geopolitical mechanics makes water a strategic commodity and its role as a strategic asset or vulnerability cannot be overestimated. Thus, seen in this context, water can become a source of both contention and cooperation in the context of contemporary world. 
Baral: Border Disputes and Its Impact...| 34

In case of Nepal and India, water issues are becoming major area of concern between two nations. In fact, many strategic thinkers are arguing that disputes relating to water will be major source of conflict between the two countries in the future. India's plan of constructing big dams and diverting the water of rivers to its own advantage has discontented in Nepal. As there are many rivers that flow from Nepal to India, the two countries must have a better understanding relating to water sharing and other attending benefits out of these rivers. However, Nepal's strategic advantage over these rivers makes it possible for her to counter-balance India on many other issues. A deep analysis of the water issues between the two countries is quiet relevant here.

\section{Ways of Solving Problems}

India and Nepal have to collaborate and coordinate their efforts to improve the situation along their border by setting up joint task forces to investigate cross-border crimes, sharing real time intelligence, conducting coordinated patrolling, re-installing missing border pillars and repairing the damaged ones and jointly developing infrastructure along the border.

Nepal and India has a long and traditional relation. It has naturally promoted social and cultural relationship among the general people of both the nations, through matrimonial relation as well. So the border demarcation issues and the problem of border management can be solved through from the level of the general people to the levels of surveyors, intellectuals, diplomats and politicians, if they make lively interactions with each other. They can highlight the issues, make convince to others by discussions. It can be made good understanding to solve the problem and issues, segment by segment grasping the difficulties of other side.

The Boundary Working Group also may pave the way to settle disputed lands once and for all. It will provide technical support when diplomatic-level talks happen. But the disputed areas would require more than just the surveyors from the two countries. The renewed border talks are a start. The surveyors from Nepal and India are working in the border for inspecting the current border and clearing the 10-yard+10-yard "no-man's land," onto which shops and farmers have encroached from both sides. They are also developing a system to address cross-border occupation and local land disputes. As a result of the updated border, people living along the frontier may soon find their land has changed countries. Families who find their land has switched nationalities will be given options to accept compensation for their land and move, or switch nationalities.

The most important thing is the dedication and willingness to resolve the issues, since border business is a matter of equal participation from both the parties. Nothing can be happened if only one country is willing, eager and hurried. It needs the equal spirit from both sides. So if, Nepal and India both have willingness to resolve the issues of Susta and Kalapani based on treaties, agreements made earlier, it wouldn't take longer than a few hours of dialogues. However, the dialogue will be in between the executive powers of both the countries. My knowledge and experience say, India could ask Nepal for leasing Kalapani area for may be 100 years, if India thinks it is a strategic point for India and in return Nepal could ask to India for leasing a corridor from Kakarbhitta, Nepal to Bangalabandha, Bangladesh for trade and transit facilitation. It is about an hour drive for heavy containers and that's the most efficient and effective route for trade facilitation for Nepal.

\section{Conclusion}

This discrepancy in locating the source of the Kali river and the main channel of the then Gandak River during the Sugauli Treaty period, led to boundary dispute between Nepal and India, with each 
country producing maps supporting their own claims. Major disputes and problems arose in the case of river boundary due to erratic changes in the river courses in Terai region.

Various minor issues have been resolved and erected subsidiary/additional boundary pillars, maintenance of existing BPs, relocation of missing BPs and prepared strip-maps of the resolved areas. In fact, the Joint Technical Boundary Committee (JTBC) worked for 26 years and completed 98 percent of the boundary work. The remaining 2 percent of the border business or $37 \mathrm{~km}$ in Narsahi-Susta and Kalapani segment of the total span of Nepal-India border was not resolved by JTBC, because of divergence of opinion and basic materials. This unsettled portion of border consists of Kalapani-Limpiyadhura encroachment $17 \mathrm{~km}$, Susta $20 \mathrm{~km}$. There are encroachments in Susta and Kalapani segment and cross-border occupation along the Nepal-India border in riverine sectors. The prominent areas have been identified as Kalapani-Limpiyadhura and Narsahi-Susta area after the Joint technical boundary committee resolved all other issues excluding Kalapani and Susta. The main reason and issues of the boundary business with India is the border encroachments and disputes on mostly cross-border occupations, divergence of opinion on basic materials.

So far as the border management is concerned, open border system has created so many problems and it has affected in social and economic aspects for both Nepal and India. The most sensitive issues these days are the free movement of the terrorists and transportation of illegal arms and ammunitions across the open border. This is quite harmful for both the countries. An uncontrolled, unrestricted and opened border constitutes the breeding ground for terrorism, criminal, illegal and anti-social activities. Keeping in view the welfare and development of general people of both the nations, there is an urgent need to manage and regulate the free movement of people. The time has been changed much from peacefulness to disturbing and troublesome. General people of both the countries are feeling panicky and fearfulness due to current circumstances in the South Asian region. It has to be made joint efforts to review the impact of open border system through dialogues and negotiations. It must come to the conclusion jointly to make the border restricted for the terrorist, controlled for smugglers, checked for the criminals, stopped for narcotic holders but managed for the genuine passengers and regulated for legal export and import.

\section{References}

Aitchison C. U. (1863). A Collection of Treaties, Engagements and Sanads Relating to India and Neighbouring Countries, Calcutta, Bengal Printing Press.

Shrestha, B.N. (2003). Border Management of Nepal, Bhumichitra Co. Pvt. Ltd.

Kansakar,V. S. (2001). 'Nepal India Open Border: Problems and Challenges,” keynote paper presented at the Seminar on Nepal India Open Border: Pros and Cons,organised by Institute of Foreign Affairs, Kathmandu and sponsored by Friedrich- Ebert-Stiftung, held in Nepalganj (19 April 2001), Biratnagar (3 May 2001) and Birganj (17 May 2001).

Kansakar, V. S. (2001). "Nepal India Open Border: Nature, Pattern and Socio-cultural Implications," in India and Nepal: Aspects of Interdependent Relations, edited by Ramakant and B. C.Upreti, Delhi, Kalinga Publications (pp. 1-14).

Kirkpatrick, W. (1801). An account of the Kingdom of Nepal(substance of observations made during mission to the country in 1793),London,w.Miller.

Malhotra, I. (1970). "India-Nepal Relations: Delhi’s Diplomacy on Trial”, The Statesman, 12 June. 
Baral: Border Disputes and Its Impact...| 36

Mehata, A. K. (2001). “ Problem of Terrorism and Other Illegal Activities on Indo-Nepal Border: Issues in Effective Border Management," in India and Nepal: Aspects of Interdependent Relations edited by ramakanta and B.C.UpretiDelhi,Kalinga publications(1-14)

Sriman, N. (1970). Nepal and India: An Exercise in Open Diplomacy, New Delhi scholar print point.

Shrestha, Buddhi Narayan, Border Management in the context of National Security (in Nepali2002), Bhumichitra Co. P. Ltd, Kathmandu.

Shrestha, HiranyaLal,Kalapani and Source of Kali (in Nepali-2000),National Peoples Publication, Kathmandu.

Shrestha, Hiranya Lal, Kalapani and Source of Kali (in Nepali-2000), National Peoples Publication, Kathmandu.

Treaties, Engagements and Sanads relating to India and neighbouring countries Vol XIV by C.U. Aitchison, 1929.

Husain,Asad (Kansakar, VidyaBir Singh (2001) "Nepal India Open Border: Nature, Pattern and Socio-cultural Implications," in India and Nepal: Aspects of Interdependent Relations, edited by 1863): British India's Relations with the Kingdom of Nepal 1857-4 London,George Allen. 